\title{
Strengthened family planning is critical to help accelerate the reduction of maternal mortality in Indonesia [version 1; peer
}

\section{review: 1 approved]}

\author{
Budi Utomo1,2, Nohan Arum Romadlona (Di)1 \\ ${ }^{1}$ Knowledge Hub for Reproductive Health, University of Indonesia, Depok, West Java, 16424, Indonesia \\ ${ }^{2}$ Department of Biostatistics and Population Studies, Faculty of Public Health, University of Indonesia, Depok, West Java, 16424, \\ Indonesia
}

\author{
V1 First published: 09 Sep 2021, 10:904 \\ https://doi.org/10.12688/f1000research.55417.1 \\ Latest published: 09 Sep 2021, 10:904 \\ https://doi.org/10.12688/f1000research.55417.1
}

\begin{abstract}
The still stubbornly high maternal mortality ratio challenges Indonesia to improve health program strategies to achieve the Sustainable Development Goal 3.1 target of a maternal mortality ratio below 70 per 100,000 live births by 2030 . Indonesia has already adopted maternal-neonatal health experts' recommendation of four core program strategies to reduce maternal mortality: (1) family planning with related reproductive health services; (2) skilled care during pregnancy and childbirth; (3) timely emergency obstetric care; and (4) immediate postnatal care (WHO, 1996). These four core strategies would reduce maternal mortality through reduced high-risk births. To be effective, however, these four core program strategies require continued strong quality assurance and central and local government support to ensure program effectiveness yielded towards widely accessible, sustained, quality family planning and maternal and neonatal emergency services. This paper provides evidence for the importance of family planning to help health program strategies to accelerate maternal mortality reduction.
\end{abstract}

Keywords

family planning, maternal mortality, Indonesia

This article is included in the Research on

Research, Policy \& Culture gateway.

\section{Open Peer Review \\ Approval Status}

1

version 1

09 Sep 2021

$$
\text { view }
$$

1. Maria Gayatri (ID), National Population and Family Planning Board, East Jakarta,

Indonesia

Any reports and responses or comments on the article can be found at the end of the article. 
This article is included in the Sociology of

Health gateway.

Corresponding author: Nohan Arum Romadlona (arumnohan@gmail.com)

Author roles: Utomo B: Conceptualization, Methodology, Writing - Original Draft Preparation, Writing - Review \& Editing; Romadlona NA: Data Curation, Formal Analysis, Writing - Original Draft Preparation

Competing interests: No competing interests were disclosed.

Grant information: This work was supported by UNFPA Indonesia, Directorate of Family Health Ministry of Health Indonesia, and Global Affairs Canada (GAC) under the agreement between Faculty of Public Health Universitas Indonesia and UNFPA Indonesia relating to 2016-2019 UNFPA Country Programme for the Republic of Indonesia, signed Implementing Partner on 9 November 2016. The funders had no role in study design, data collection and analysis, decision to publish, or preparation of the manuscript.

Copyright: @ 2021 Utomo B and Romadlona NA. This is an open access article distributed under the terms of the Creative Commons Attribution License, which permits unrestricted use, distribution, and reproduction in any medium, provided the original work is properly cited. The author(s) is/are employees of the US Government and therefore domestic copyright protection in USA does not apply to this work. The work may be protected under the copyright laws of other jurisdictions when used in those jurisdictions.

How to cite this article: Utomo B and Romadlona NA. Strengthened family planning is critical to help accelerate the reduction of maternal mortality in Indonesia [version 1; peer review: 1 approved] F1000Research 2021, 10:904

https://doi.org/10.12688/f1000research.55417.1

First published: 09 Sep 2021, 10:904 https://doi.org/10.12688/f1000research.55417.1 


\section{Introduction}

The still stubbornly high maternal mortality ratio challenges Indonesia to improve health program strategies to achieve the Sustainable Development Goal 3.1 target of a maternal mortality ratio below 70 per 100,000 live births by 2030 . The available estimates of maternal mortality ratio for the period of 2000-2017 ranged widely between 175 and 350 maternal deaths per 100,000 live births (Soemantri 2014; Statistics Indonesia 2015; Hasbullah et al., 2016; WHO, 2019). ${ }^{1}$ The UNFPA Indonesia panel of mortality estimation working group, using only the past year's direct record of maternal mortality data from the Intercensal Population Survey (SUPAS) 2015, produced an estimate of 237 maternal deaths per 100,000 live births (UNFPA Indonesia, 2018). ${ }^{2}$ The Indonesian maternal mortality ratio is a paradox, as other countries with similar levels of socio-economic development have much lower maternal mortality ratios; for example, the following ratios for South-East Asian countries were measured in 2017: Cambodia 160, Indonesia 177, Malaysia 29, Myanmar 250, Philippines 121, Thailand 37, Vietnam 43, and Singapore 8 (WHO, 2019). In contrast, the maternal mortality ratios in several developed countries are much lower, amounting to 5 or below: Denmark 4 , Netherlands 5, Norway 2, Spain 4, and Sweden 4 (WHO, 2019).

Indonesia has already adopted maternal-neonatal health experts' recommendation of four core program strategies to reduce maternal mortality: (1) Family planning with related reproductive health services; (2) skilled care during pregnancy and childbirth; (3) timely emergency obstetric care; and (4) immediate postnatal care (WHO, 1996). These four core strategies would reduce maternal mortality through reduced high-risk births. Unlike the other core strategies, family planning would also reduce maternal mortality via reduced births. Voluntary family planning would reduce unwanted pregnancies and the four 'too' high-risk births: too old, too young, too frequent, and too many births. To be effective, however, these four core program strategies require continued strong quality assurance and central and local government support to ensure program effectiveness yielded towards widely accessible, sustained, quality family planning, and maternal and neonatal emergency services. This paper provides evidence for the importance of family planning to help health program strategies to accelerate the reduction in maternal mortality.

\section{Policy outcomes and implications}

Benefits of family planning

Family planning is a strategic nation-building program with an intended double effect: (a) promote healthy mothers, children, families and communities (Smith et al., 2009); and (b) ensure sustainable development by balancing population with the state of development and the living environment (Starbird et al., 2016). Family planning protects women from unwanted and high-risk pregnancies. Women with an unwanted pregnancy might try a number of means to abort their pregnancy (Hull et al., 1993). These women, in a setting where abortion is illegal, tend to seek care with a clandestine provider who performs unsafe abortions, facing high risks of maternal complications and mortality.

Family planning, through the use of contraceptives, regulates pregnancies so that they occur only when women or couples are physically, mentally and socially ready. The four 'too' pregnancies - too young or too old to be pregnant, too little time between pregnancies, or too many pregnancies - put women and their pregnancy at a high risk of maternal complications and death. Effective family planning, by ensuring every pregnancy is at the lowest risk of maternal complications and death, would promote healthy pregnancies and newborns. Family planning, through reduced births, controls population growth and balances it with socio-economic development and the living environment, and through reduced high-risk births reduces the risk of maternal mortality for each birth. Voluntary family planning ensures sustainable development and builds healthy generations (Aspen Institute, 2011). Moreover, one review suggests investing in family planning could accelerate achievements for all the Sustainable Development Goal themes of People, Planet, Prosperity, Peace, and Partnership (Starbird et al., 2016).

\section{The success and the declining quality of family planning in Indonesia}

The Indonesian family planning program has been considered successful in reducing fertility and maternal mortality. Within three decades of its initiation, from the early 1970s to early 2000s, the program brought the contraceptive prevalence rate from 5\% to over 50\%, and brought down the total fertility rate from 5.0 to 2.3 (Hull and Mosley, 2009). The program's success was related in part to international support and the government's strong commitment to family planning. However, social and political changes linked to decentralizing development occurring in the early of 2000s, have disrupted the progress of many development programs, including family planning. Since then, many development

${ }^{1}$ Lower estimates provided by the Maternal Mortality Estimation Inter-Agency Group (MMEIG) WHO, UNICEF, UNFPA, World Bank Group and the United Nations Population Division; and higher estimates provided by Badan Pusat Statistik (Indonesia Statistics). See also Hasbullah et al., 2016; Soemantri, 2014.

${ }^{2}$ Using one-year recall of maternal death, instead of five-year recall as done in the official estimate, would result in less under-reporting of death. 
programs have slowed down or even stagnated to reflect decelerated developments (Bappenas, 2007, 2011) and the total fertility and contraceptive prevalence rates, used as the family program achievement indicators, had stagnated around 2.6 and 55\%, respectively (BPS, BKKBN, Kemenkes, and ICF International, 2018).

To this day, the regional disparity of contraceptive access and service quality remains striking. The national modern contraceptive prevalence rate among currently married women accounts for $57 \%$, but the rates remain much lower for some parts of Sumatra, Nusa Tenggara, Sulawesi, Maluku and Papua (BPS, BKKBN, Kemenkes, and ICF International, 2018:152). The use of short-term contraceptive methods dominate.

Geographic isolation hampers women's access to long-term contraceptive methods, i.e. intrauterine device (IUD) and sterilization (Febriani, 2012). The unmet need for contraception (UNC) - defined as the percentage of women of reproductive age who want to postpone pregnancy or do not want more children, but are not using contraceptives - has remained stable during the past three decades, at 12\% in 1991 and 11\% in 2017 (BPS, BKKBN, Kemenkes, and ICF International, 2018:108). The still relatively high UNC translates to around five million women of reproductive age who are sexually active being at risk of unwanted pregnancies (BPS, 2018) ${ }^{3}$.

The low use of contraceptive or the high UNC implies low access by women or couples to family planning information and services. Several factors associated with low use of contraceptives include: fear of contraceptive side effects, husband disapproval of use of contraceptive, and cost constraints (Bongaarts et al., 2012). In Papua, the public misperception that contraceptive use would cause infertility has prompted the high UNC (Tjiong, 2012). Common traditional beliefs unfavorable to family planning, such as 'a family should have a boy' and 'many children bring a lot of luck', have persisted in some communities, restricting the search for family planning services (Febriani, 2012).

The family planning program's effectiveness has declined during the past decade and a half, as indicated by the increasing dropout rates of contraceptive use and the shift from predominantly long-term to predominantly short-term contraceptive methods. The proportion of women who started using a contraceptive, but discontinued use within 12 months has increased from 25\% during 1991-2012 to 34\% in 2017 (IDHS). Side effects and/or health concerns were the most cited reasons for contraceptive use discontinuation (BPS, BKKBN, Kemenkes, ICF International, 2018:101).

The shift in contraceptive method mixed (Figure 1) reflects the declining quality of the family planning program (Hayes, 2012). The cost of contraceptives is one key factor limiting the choice of contraceptive method. The poorest quintile population used less effective short-term methods, while the richest used more effective long-term contraceptive methods (BPS, BKKBN, Kemenkes, and ICF International, 2018:117-118). For the provider, offering short-term contraceptive

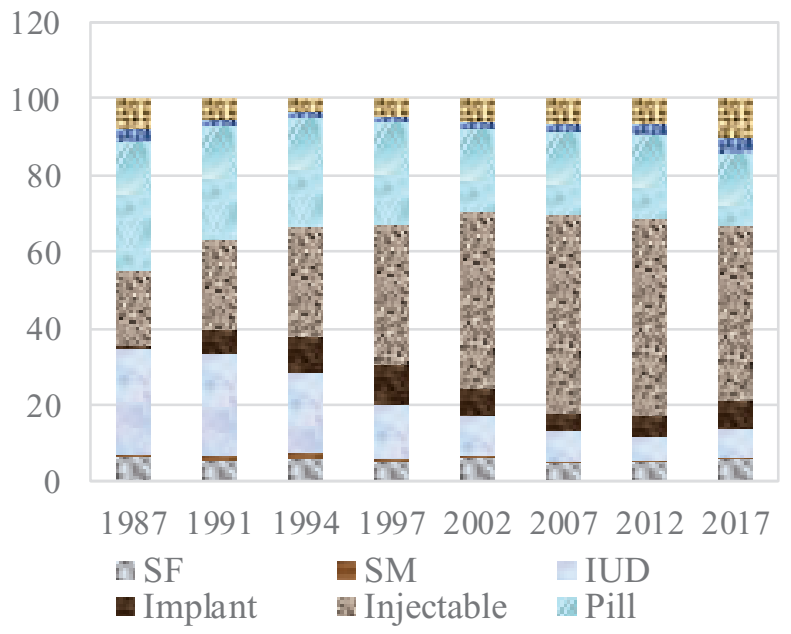

Figure 1. Contraceptive method mix, Indonesia 1987-2017 (IDHS 1987-2017). SF (sterilization of female); SM (sterilization of male); IUD, intrauterine device. Source: Indonesia Demographic Health Survey 1987-2017.

${ }^{3}$ Computation based on the unmet need for contraception and the sexually active reproductive aged women 2017 from Indonesia data population projection 2015-2045. 
methods is more practical than providing long-term ones; while for the clients the use of injections is simpler as it requires only one visit every three-months and does not need invasive examination (Febriani, 2012).

The country's two main sources of family planning services, i.e. health centers and midwife private practices, have a limited capacity to offer quality services. The national survey of health centers conducted in 2011 showed $61 \%$ did not have a counseling room, $19 \%$ operated in a dilapidated building, $28 \%$ had no clean water infrastructures, and $55 \%$ did not have a safe waste disposal system (Kemenkes, 2012). One study in Bogor Regency reported most midwife private practices did not offer counseling on contraceptive options (Habsjah, 2009). Proper counseling is critical to assist clients in choosing the most suitable method of contraceptive for them, to ensure contraceptive use effectiveness and minimize side effects (Bruce, 1990). One field study demonstrated that enhancing counseling and clinical management skills of service personnel could lead to increased use of long-term contraceptives (Febriani, 2012).

\section{Family planning reduces maternal deaths}

Family planning reduces maternal deaths via two mechanisms: reduced births and reduced high-risk births (Ross and Blanc, 2012). Reduced births lead to reduced maternal deaths since the probability of a fatal outcome decreases with a lower number of pregnancies. Reduced high-risk births lead to a lowered risk of maternal death per birth. Worldwide studies have provided consistent results showing that family planning programs reduce fertility and contribute highly to reducing maternal mortality (WHO, 1996; Ross JA et al., 2012; Cleland et al., 2012; Ahmed et al., 2012).

\section{International evidence}

Using a counterfactual modeling approach, Ahmed et al. (2012) showed that the contribution of contraceptive use to reducing maternal deaths across 172 countries ranged from 7\% and 60\%, or 44\% overall (Ahmed et al., 2012). An additional $29 \%$ reduction of maternal deaths could happen by satisfying the UNC. The size of family planning's contribution to reducing maternal deaths depends on the levels of contraceptive use and UNC. Stover and Ross (2010) in a different analysis showed that the increasing contraceptive use in all developing countries studied from the historically low levels to a high-level is parallel to $31 \%$ of the overall decline of maternal mortality ratio (Stover and Ross, 2010).

\section{Indonesia evidence}

Maternal deaths decomposition analysis

A recent study based on a decomposition analysis showed that the Indonesian family planning program has contributed highly to reducing maternal mortality (Utomo et al., 2021). The analysis showed that the Indonesian family planning program averted 150.5 million births between 1970-2017, a 40.7\% reduction in births. The majority of the 94.8 million averted births occurred after the year 2000 when the contraceptive prevalence rate had already surpassed 50\%. The Indonesian national family planning program averted 592.5 million maternal deaths between 1970 and 2017, a 40.4\% reduction. Of the maternal deaths averted, 57\% occurred after the year 2000.

Survival analysis: use of contraceptive and the reproductive aged women risk of mortality

The Cox regression survival analysis of women of reproductive age, using panel data from the Indonesia Family Life Survey rounds: 1993, 1997, 2000, 2007, and 2014, showed the use of contraceptives reduced the risk of mortality of reproductive-aged women (Besral et al., 2019). The analysis prospectively evaluated the effect of contraceptive use duration on survival status of women of reproductive age, controlling for socio-economic, demographic and health service factors (Table 1). This complete analysis will be presented in the separate paper.

Table 1. Cox regression survival analysis of women of reproductive age by contraceptive use duration, the Indonesia Family Life Survey rounds 1993, 1997, 2000, 2007, and 2014 ( $n=11,492$ women of reproductive age).

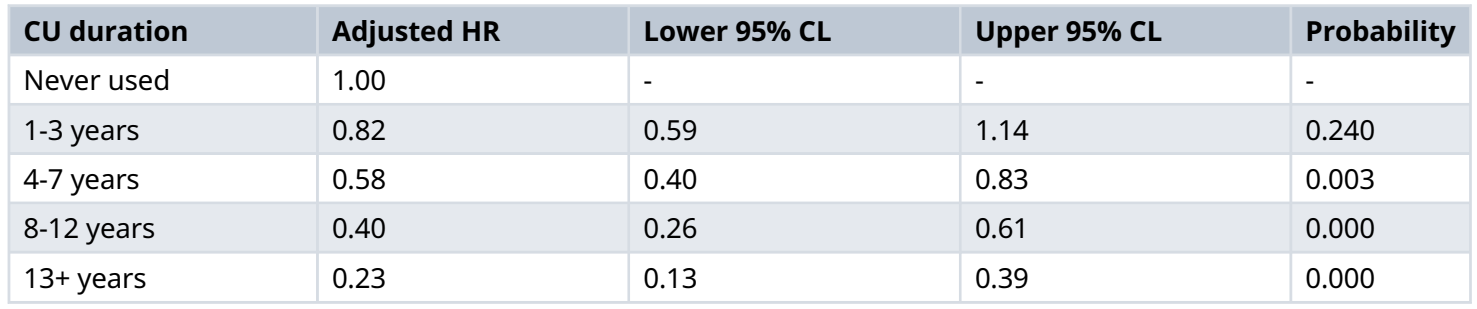

$\mathrm{HR}=$ Hazard rate; $\mathrm{CL}=$ Confidence level of hazard rate; $\mathrm{CU}=$ Contraceptive use.

Statistically controlled by demographic, socio-economic, living environment, and health service factors.

Data sources: Indonesia Family Life Survey 1993, 1997, 2000, 2007, 2014. 
The analysis demonstrates the dose-response effect of contraceptive use duration on reducing the risk of mortality in women of reproductive age. The longer the use of contraceptives, the lower the number of women of reproductive age at risk of mortality. The dose-response effect of contraceptive use duration on reducing women of reproductive age's risk of death persists, even controlled by the woman's education, age, residential site, household socio-economic status, and health service access factors. Women of reproductive age with contraceptive use durations of more than 13 years had a four times lower risk of death than the women of reproductive age who never used a contraceptive.

\section{SUPAS 2015 and Village Potential Census (PODES) 2014 data analysis: contraceptive use and maternal mortality}

A community-level ecological multivariable log-linear regression analysis using SUPAS 2015 and Village Potential Census (PODES) 2014 data showed that contraceptive use lowers the risk of maternal mortality (Aryanty et al., 2021). The analysis included a sample of 40,728 census blocks (each block with a sample size of 16 households) dispersed across the country major islands. The PODES 2014 database was merged with the SUPAS 2015 dataset to obtain the health service supply variables. Census blocks with high use of contraceptive had lower risks of maternal mortality than the census blocks with low use of contraceptive (Figure 2). The analysis also found a lower risk of maternal mortality associated with higher hospital densities in the locality; in addition, the lower the household's socio-economic status, the higher the risk of maternal mortality. Surprisingly, a higher traditional birth attendant (TBA) density in the village led to a higher risk of maternal mortality. Hence, the presence of TBAs in the village likely slows down the maternal complication case referral process.

Simulation: could strengthened family planning further reduce maternal mortality?

Indonesia's maternal mortality ratio has been declining, with an annual reduction rate of six points from over 500 in the early 1970s, to slightly below 300 maternal deaths per 100,000 live births in the early 2000s (MoH, 2019; Cameron, et al., 2019; Fortney et al., 1988). Since then, the maternal mortality ratio declining trend has slowed down, or even stagnated to an annual reduction rate of only two points (Figure 3). Following this slowed down declining trend, the maternal mortality ratio is predicted to be at 243 by 2030, which is 173 points above the SDG 3.1 target of a maternal mortality rate below 70. Additional programmatic efforts will be required to achieve the SDG 3.1 target.

How could family planning further reduce maternal mortality? The future potential contribution of family planning to reduce maternal mortality is clear: (a) the UNC is still relatively high, reported at $11 \%$ in 2017 (ranging by province from $4 \%$ to $24 \%$ ) (BPS, BKKBN, Kemenkes, and ICF International, 2018: 293), and (b) the notable geographical inequality of contraceptive service access, i.e. the national average modern contraceptive prevalence rate among currently married

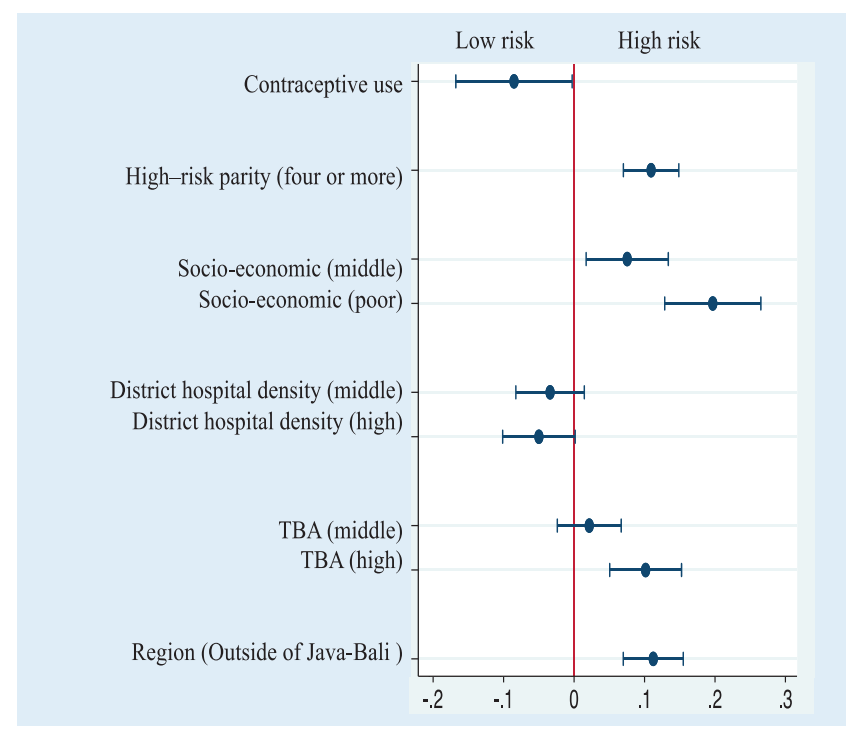

Figure 2. Odd ratios of multi-variable log-linear regression on risk of maternal death. Reference = The left side below zero represents low risk, the right side above zero represents high risk. TBA = traditional birth attendant. Figure source: Aryanty et al. (2021). Data sources: Indonesia Intercensal Survey 2015 (SUPAS) and Village Potential Census 2014 (PODES). 


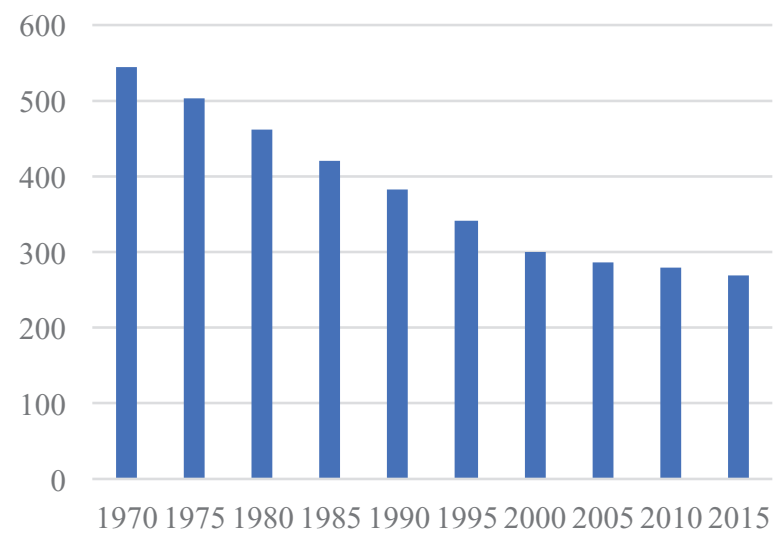

Figure 3. Indonesia maternal mortality ratio trend, 1970-2015. Sources: Population Censuses (1971, 1980, 1990, 2000, and 2010) and Inter-Censal Population Surveys (1985, 1995, 2005, and 2015).

women was $57.2 \%$ in 2017 , while as many as 15 provinces had a modern contraceptive prevalence rate of $50 \%$ or below, and five provinces had a rate below 45\% (BPS, BKKBN, Kemenkes, and ICF International, 2018: 290). Thus, family planning has the potential to reduce the UNC and increase the contraceptive prevalence rate, particularly in these 15 provinces. Reducing the UNC means reducing high-risk pregnancies and, thus, reducing the risk of maternal mortality per birth. Similarly, increasing the contraceptive prevalence rate means reducing the number of births and, thus, reducing the risk of maternal death per mother.

Utomo et al. (2021) carried out a simulation to compare declining trends of maternal mortality ratio between 2017-2030 depending on three different situations: (1) continued stabilization of a contraceptive prevalence rate (CPR) of $63 \%$ and UNC of 10\%; (2) CPR increases linearly from $63 \%$ to $70 \%$ and UNC reduces from $10 \%$ to $7 \%$; and (3) CPR increases linearly from $63 \%$ to $75 \%$ and UNC reduces from $10 \%$ to $5 \%$. The simulation analysis showed that by increasing CPR from $63 \%$ to $70 \%$ and reducing UNC from $10 \%$ to $7 \%$ (Situation 2) as compared to Situation 1 corresponding to stabilization of CPR and UNC, family planning could further avert 35,897 additional maternal deaths (19.5\%) between 2017 and 2030. Further, by increasing CPR from 63\% to 75\% and reducing UNC from 10\% to 5\% (Situation 3), as compared to Situation 1, family planning could further avert 53,247 additional maternal deaths (28.9\%) between 2017 and 2030. Regarding the reduction of the maternal mortality ratio in the period 2017-2030, the maternal mortality ratio under Situation 1 (stabilized family planning) would reduce from 255 to 221 ; however, under Situation 2, it would decrease from 255 to 164, while under Situation 3, it would reduce from 255 to 125 . This simulation analysis demonstrates that a strengthened family planning, increasing CPR from $63 \%$ to $75 \%$ and reducing UNC from $10 \%$ to $5 \%$, could bring down the maternal mortality ratio by about $50 \%$, to reach 125 maternal deaths per 100,000 live births. With a strengthened family planning program, the health sector's task of accelerating the decrease of maternal mortality rates becomes less of a burden, not to bring down MMR from 255 to 70 but from 125 to 70 to achieve the SDG 3.1 target by 2030 .

\section{Actionable recommendations}

The National Family Planning Board $(B K K B N)$ is developing strategic plans for a rights-based family planning program (BKKBN, 2019). The rights-based family planning program, if implemented as planned, would contribute to improving the quality of human resources, through training and provision to health practitioners that represent and covered geographic inequities in health resources, in provinces and districts in the eastern part is relatively under-developed compared to Java-Bali. For decentralized family planning, the national strategic plans should be translated to the district/ city-locally strategic plans to guide micro-managing family planning programs and services. Attention needs to be directed in priority towards rectifying remaining geographic and socioeconomic inequities in the access to accurate information and services, more effectively addressing local barriers and constraints to family planning uptake, providing informed choices across a full range of contraceptive methods, and improving the service quality. Challenges to decentralized rights-based family planning services would include: (1) coordination of stakeholders; (2) local institutional capacity strengthening; (3) the family planning information system; (4) provision of rights-based family planning services; (5) mechanisms of purchasing and financing family planning services; (6) evidence-based advocacy to local leaders; and (7) integration of family planning into other reproductive health services. 


\section{Conclusions}

The analyses presented above show that a family planning program is a strategic national intervention to help reduce maternal mortality. Substantial reductions in maternal mortality between the years 1970 and 2017 can be attributed to the successes of the national family planning program. A decline in quality of family planning, has been occurring since the early 2000s, parallel to social change and reduced international and government support; however, this could potentially be reversed towards strong voluntary family planning, as the country has experience of managing successful family planning during the first three decades from its initiation. Government support and strengthening national and local governance to manage effective voluntary family planning is critical to ensure quality family planning and reach women in need.

\section{Data availability}

Underlying data

The data used in the policy brief were produced by the Government of Indonesia, Central Statistics Bureau (Badan Pusat Statistik - BPS), please consult the BPS website for further information on publications and access to data. The Indonesian Demographic and Health Survey (IDHS) reports and data files used in the study are accessible via the DHS/IRC website. Indonesia Family Life Survey are available online.

Data sources of Figure 1

- Raw data and report from Indonesia Demographic Health Survey 1987, 1991, 1994, 1997, 2002, 2007, 2012, and 2017.

- This data is open access and can be accessed at https://www.dhsprogram.com/.

Data sources of Table 1

- Raw data from Indonesia Family Life Survey 1993, 1997, 2000, 2007, 2014.

- This data is open access and can be accessed at https://www.rand.org.

Data sources of Figure 2

- Indonesia Intercensal Survey 2015 (SUPAS) and Village Potential Census 2014 (PODES) from Central Statistics Bureau (Badan Pusat Statistik - BPS)

- This raw data is not open for public and need to consult to BPS to access the data. Report is available and can be accessed at https://www.bps.go.id/v.

- This figure is originally presented from our publish research that can be accessed at https://doi.org/10.1186/ s12978-020-01022-6

Data sources of Figure 3

- Population Censuses (1971, 1980, 1990, 2000, and 2010) and Inter-Censal Population Surveys (1985, 1995, 2005, and 2015)

- Data from figure 3 was generated from the report of Population Censuses and Inte-censal Population Surveys that can be accessed at https://www.bps.go.id/. 
Aryanty RI, Romadlona N, Besral B, et al.: Contraceptive use and maternal mortality in Indonesia: a community-level ecological analysis. Reprod Health. 2021; 18: 42.

Publisher Full Text

Aspen Institute: Population Growth, Reproductive Health and Sustainable Development Policy Brief, December. Global Leaders Council for Reproductive Health. 2011;

Reference Source

Bappenas: Report on the Achievement of Millennium Development Goals in Indonesia. Jakarta; 2007.

Bappenas: Report on the Achievement of Millennium Development Goals in Indonesia. Jakarta; 2011.

Besral, Kurniawan R, Utomo B, Aryanty RI, et al.: Contraceptive use among women of reproductive age reduces the risk of maternal mortality - Analysis of panel data of IFLS 1993-2014. 2019. Manuscript.

Bongaarts J, Cleland J, Townsend JW, et al.: Family Planning Programs for the 21st Century: Rationale and design. New York: Population Council 2012.

Bruce J: Fundamental Elements of the Quality of Care: A Simple Framework. Stud Fam Plann. 1990; 21(2): 61-91.

PubMed Abstract

Cameron L, Contreras Suarez D, Cornwell K: Understanding the determinants of maternal mortality: An observational study using the Indonesian Population Census. PloS one. 2019; 14(6): e0217386. Publisher Full Text

Cleland J, Conde-Agudelo A, Peterson $\mathrm{H}$, et al.: Contraception and health. Lancet. 2012; 380(9837): 149-156.

Publisher Full Text

Febriani E: The Regency Family Planning Situation Analysis: Report. Jakarta: UNFPA Indonesia; 2012.

Febriani E: Report of Situation Analysis Result of the Family Planning Program in the Regency. Jakarta: UNFPA Indonesia; 2012.

Fortney JA, Susanti I, Gadalla S, et al.: Maternal mortality in Indonesia and Egypt. Int J Gynaecol Obstet. 1988; 26(1): 21-32.

PubMed Abstract | Publisher Full Text

Habsjah A: Contraception in the Decentralization Era in Indonesia. The Asia-Pacific Resource \& Research Centre for Women (ARROW). Kuala Lumpur, Malaysia; 2009.

Hasbullah MS, Surbakti IM, dan Handiyatmo D: Kematian Maternal di Indonesia Hasil Supas 2015. Forum Masyarakat Statistik. Statistical and Policy Brief. Edisi 8; 2016.

Hayes AC: The UNFPA-BKKBN Partnership Regarding Family

Planning under the $8^{\text {th }}$ Country Programme. UNFPA, Jakarta: Strategy Paper; 2012.

Hull TH, Mosley H: Revitalization of Family Planning in Indonesia. Jakarta:

The Government of Indonesia and United Nations Population Fund; 2009.
Hull TH, Sarwono SW, Widyantoro N: Induced Abortion in Indonesia. Stud Fam Plann. 1993; 24(4): 241-251.

PubMed Abstract

MoH (KemKes): Laporan Akhir Riset Fasilitas Kesehatan 2011, Puskesmas. Jakarta: Badan Litbangkes; 2012.

Reference Source

$\mathrm{MoH}$ (Kemkes): Profil Kesehatan Indonesia Tahun 2018. Jakarta:

Kementerian Kesehatan RI; 2019; 2019. 978-602-656-446-4.

Ross JA, Blanc AK: 'Why Aren't There More Maternal Deaths? 'A

Decomposition Analysis'. Matern Child Health J. 2012; 16: 456-463.

Published online: 24 March 2011

PubMed Abstract | Publisher Full Text | Free Full Text

Smith R, Ashford L, Gribble J, et al.: Family Planning Saves Lives. Fourth ed.

Washington, DC: Population Reference Bureau; 2009.

Reference Source

Soemantri S: Telaah Perkiraan AKI (MM Ratio) Untuk Indonesia. Forum Masyarakat Statistik. Statistical and Policy Brief. Edisi 4; 2014

Statistics Indonesia (BPS): Proyeksi Penduduk Indonesia 2015-2045 Hasil SUPAS 2015. Jakarta, Indonesia: BPS; 2018; 978-602-438-189-9.

Statistics Indonesia (BPS), National Population and Family Planning Board (BKKBN), Ministry of Health (Kemenkes), and ICF International: Indonesia Demographic and Health Survey 2017. Jakarta, Indonesia: BKKBN, BPS, Kemenkes, and ICF; 2018.

Starbird E, Norton M, Marcus R: Investing in Family Planning: Key to Achieving the Sustainable Development Goals. Glob Health Sci Pract. 2016; 4(2): 191-210.

PubMed Abstract | Publisher Full Text | Free Full Text

Stover [, Ross ]: How increased contraceptive use has reduced maternal mortality. Matern Child Health J. 2010; 14: 687-695.

PubMed Abstract | Publisher Full Text

Tjiong R: Isu Strategis KB di Papua. Presented at Development of Family Planning Training Packaged, Jayapura, 3-5 July. 2012.

UNFPA Indonesia: Maternal Mortality Estimation in Indonesia: A Panel

Review. Report. 2018.

Publisher Full Text

Utomo B, Sucahya PK, Romadlona NA, et al.: The impact of family

planning on maternal mortality in Indonesia: what future

contribution can be expected? Popul Health Metr. 2021; 19: 2

PubMed Abstract | Publisher Full Text | Free Full Text

WHO: Mother-baby package: implementing safe motherhood in countries. Geneva: World Health Organization; 1996. (accessed 24 March, 2019).

Reference Source

WHO: Trends in maternal mortality 2000 to 2017: estimates by WHO, UNICEF, UNFPA, World Bank Group and the United Nations

Population Division. Geneva: World Health Organization; 2019. Licence: CC BY-NC-SA 3.0 IGO. 


\section{Open Peer Review}

\section{Current Peer Review Status:}

\section{Version 1}

Reviewer Report 04 October 2021

https://doi.org/10.5256/f1000research.58989.r94219

(C) 2021 Gayatri M. This is an open access peer review report distributed under the terms of the Creative Commons Attribution License, which permits unrestricted use, distribution, and reproduction in any medium, provided the original work is properly cited.

\section{Maria Gayatri}

Family Planning and Family Welfare Research and Development Unit, National Population and Family Planning Board, East Jakarta, Indonesia

The manuscript submitted by Budi Utomo and Nohan Arum Romadlona aims to provide some strategies based on the evidence to strengthen family planning program in Indonesia. Overall, the article presents evidence that would be of interest the Government and community of scientists concerned with the problem of maternal and child health. Prior to indexing, the following points should be addressed.

1. Please provide more detailed action recommendations.

2. Please add some evidence related to the performance of field workers in the family planning programs.

Thank you. The article is already comprehensive.

Competing Interests: No competing interests were disclosed.

Reviewer Expertise: Family planning program, biostatistics

I confirm that I have read this submission and believe that I have an appropriate level of expertise to confirm that it is of an acceptable scientific standard. 
The benefits of publishing with F1000Research:

- Your article is published within days, with no editorial bias

- You can publish traditional articles, null/negative results, case reports, data notes and more

- The peer review process is transparent and collaborative

- Your article is indexed in PubMed after passing peer review

- Dedicated customer support at every stage

For pre-submission enquiries, contact research@f1000.com 